\title{
Researchers fight for a voice
}

\section{Washington}

THE new US federal budget still looks like a victory for the biomedical community with a healthy increase of some 10 per cent granted for the National Institutes of Health (NIH). But as the dust settles, stories are emerging of a full year of behind-the-scenes battling which included not only the usual combat between research lobbyists and congressional staff but also new infighting among scientists themselves. At one point a split between groups backing individual investigators and those representing the universities threatened the increase of nearly $\$ 1,000$ million in biomedical research funding in the new appropriations.

The story began early this year, when a group of biologists broke away from the traditional lobbying pack and hired a former congressman named Peter Kyros to be their own Washington representative. That raised eyebrows, especially among the 164 other research and academic groups who, as members of a powerful organization known as the 'ad hoc coalition', carefully craft a science lobbying script each year.

But since then, in a series of questionable moves, the biologists, led by the American Society for Cell Biology (ASCB), have brought the issue of research lobbying to a head, pitting basic researchers against their own institutions.

At the core of the dispute is the way science is represented in Washington. The university groups, especially the Association of American Universities (AAU) and the American Association of Medical Colleges (AAMC), have proved to be remarkably effective in lobbying for more money for research. But in the process, the associations also stressed the need for "generational equity". What that means, the academic lobbyists say, is that new funds should be shared between grants, and money for new facilities and "infrastructure" - provisions for the next generation of researchers.

But in the opinion of the bench scientists, who in 1990 faced the first real decrease in new and competing grants from NIH in recent history, there may not be another generation of researchers without new grants.

Concerned that their message was not getting across, the cell biologists refused to join the ad hoc coalition unless they were given a seat on the steering committee where they could ensure that their concerns were being addressed. Denied that, they took matters into their own hands, unleashing Kyros to impress on Congress the value of research by individual investigators.

One of Kyros's first moves was to have several biologists testify at a hearing in favour of more 'RO-1' grants, the basic individual NIH award. Noting that in 1990, new and competing RO-1s fell to 4,600 - nearly 2,000 less than two years previously - the scientists asked for $\$ 200$ million in new funding, enough (assuming an average grant size of $\$ 200,000$ ) to support 1,000 new awards. All this would have been fine, had not Congress already been contemplating an increase of about five times as much.

"It's like going to your richest donor and asking him to buy you lunch", is how AAU president Robert Rosenzweig describes the hearing. One staff member of the appropriations committee recalls: "In a scarce environment sometimes we take the lowest bidder, and they immediately became the lowest bidder". Although Congress eventually got straightened out, there was real concern at the time that the entire research lobbying process had been adversely affected.

Then last month, Kyros helped to set up a Biomedical Research Caucus - an informal group of some 33 Members of Congress who would meet researchers regularly to talk about issues of mutual interest. Unfortunately, the caucus was widely (if perhaps wrongly) perceived as a back-door lobbying effort that undermined the ad hoc coalition (see Nature 347, 505; 11 October 1990).

The dispute is symptomatic of the increasing division between the 'big science' and 'little science' camps. "There is a real tension building here", presidential science adviser D. Allan Bromley said in an interview earlier this month. "I hope [the scientists] can draw on some innate statesmanship, realizing that it is never an effective technique to blackball competing researchers in lobbying Congress." Direct contact with Congress is important, adds former NIH director James Wyngaarden, "but I'm not sure the best way to do it is with a whole bunch of splinter groups. That kind of behavior just cancels out." As of last week, there was still a good deal of bad blood between basic biomedical researchers and the academic community over the priorities of Washington lobbying. At a meeting in San Francisco earlier this month, ASCB officials decided to retain Kyros and go it alone for now, postponing any decision on whether to join the adhoc coalition. Officials from both sides describe the dispute as an unfortunate "breakdown of communications". But through the smoke, they say they can already see hints of raised sensitivities in both groups towards the needs of individual investigators as well as institutions. That alone, says one scarred veteran of this summer's lobby wars, might someday make the whole affair "almost worth it". Christopher Anderson

\section{Boston}

IN A bizarre twist to the decades-long battle over the nuclear plant at Shoreham, New Hampshire, US Department of Energy (DoE) officials are now claiming that the situation in the Middle East may bring the plant back into operation.

The fate of the plant appeared sealed in July 1989 when shareholders voted to sell the completed-but-unopened plant to the state for one dollar. Under the agreement, the state would then be responsible for decommissioning the plant. But at the time, James D. Watkins, the Energy Secretary, decried the closure as "utterly irresponsible" and pledged to make the plant's operation a personal priority.

With events in the Middle East providing the opportunity, Doe has now filed a legal brief to the Nuclear Regulatory Commission (NRC) arguing that before the decommissioning process can begin, NRC must once again reconsider the option of operating the Shoreham plant. According to the brief, the original congressional act that split the DoE from the Atomic Energy Commission enables the Energy Secretary to "order the operation of an electrical generating facility whenever the Secretary determines that there is an energy emergency

Ironically, that argument puts DoE at odds not only with New York state officials and local residents (the overwhelming majority of whom back the plant's decommissioning), but also with the Long Island Light Company (LILCO) that built Shoreham in the first place. Having sold the plant to the state, LILCO is reluctant to re-open the issue of the plant's operation.

DoE officials last week refused to comment on the brief, saying that it speaks for itself. Clearly, though, the department's contention that it could force Shoreham to open is easier to argue than it would be to implement .

Seth Shulman CNRS-

\section{NMR turns gold}

\section{Paris}

THE Centre National de la Recherche Scientifique (CNRS), the largest basic research organization in France, has awarded its 1990 Gold Medal to Professor Marc Julia. Julia is director of the chemistry department of the Ecole Normale Supérieure in Paris and is head of the CNRS 'molecular activation unit'. A member of the Académie des Sciences since 1977, Julia has pioneered new techniques in therapeutic chemistry, including the use of nuclear magnetic resonance. P.C. 